\title{
Correction to: Identification of structural breaks in the forest product markets: how sensitive are to changes in the Nordic region?
}

\section{Tahamina Khanam $^{1}$ • Abul Rahman ${ }^{1}$ • Blas Mola-Yudego ${ }^{1,2} \cdot$ Jouni Pykäläinen $^{1}$}

Published online: 22 July 2019

(C) Springer Nature B.V. 2019

\section{Correction to: Mitig Adapt Strateg Glob Change (2017), 22, 469-483 https://doi.org/10.1007/s11027-015-9681-9}

This paper was published on March 2017, Volume 22, Issue 3, 469-483pp, titled "Identification of structural breaks in the forest product markets: how sensitive are to changes in the Nordic region?" with errors referring to the units related to figure 1. Please see below.

a) On the text, under point "2.1 Data", where it says:

The corresponding data are in units of $1000 \mathrm{~m} 3$ Euro (Fig. 1)

\section{Should say:}

The corresponding data are in units of $x 1000 \mathrm{m3}$ (Fig. 1)

b) On the caption of fig. 1, where it says:

Export, import and domestic consumption of forest products in Finland and Sweden, 1964$2012(€ / 1000 \mathrm{~m} 3)$

\section{Should say:}

Export, import and domestic consumption of forest products in Finland and Sweden, 19642012 (x1000 m3)

The online version of the original article can be found at https://doi.org/10.1007/s11027-015-9681-9

Tahamina Khanam tahakh@student.uef.fi

1 School of Forest Sciences, University of Eastern Finland, PO Box 111, 80101 Joensuu, Finland

2 Department of Crop Production Ecology, Swedish University of Agricultural Sciences, PO Box 7043 , 75007 Uppsala, Sweden 
c) On figure 1, axis, where it says:

$1000 \mathrm{~m} 3$ euros

Should say:

$x 1000 \mathrm{m3}$

The author apologizes for the inconveniences occurred, and thank the editor for the time invested on this paper.

Publisher's note Springer Nature remains neutral with regard to jurisdictional claims in published maps and institutional affiliations. 